\title{
照明の色が豚の発育性，産肉性および脂肪組織と 筋肉の脂肪酸組成に及ぼす影響
}

\author{
山田未知・平山紀子・山田幸二*・杉田昭栄**・山内克彦
}

福島県立農業短期大学校, 西白河郡矢吹町一本木 446, 969-0292

* 郡山女子大学家政学部, 郡山市開成 3 丁目 25 番地 2 号, 963-8851

** 宇都宮大学農学部, 宇都宮市峰町 350 番地, 321-8505

（2001 年 12 月 18 日受付, 2002 年 6 月 13 日受理）

\begin{abstract}
要 約 照明の色が豚の発育性・産肉性および脂肪組織と筋肉の脂肪酸組成に及ぼす影 響について検討した。肥育前期・後期・試験期間全体の一日平均増体量および飼料要求率 は, 無灯火区, 赤色照明区, 青色照明区, 白熱灯照明区の各区間に有意な差は見られなかっ た。枝肉歩留および背脂肪の厚さにおいても各区間に有意な差は見られなかった。背脂肪 の脂肪酸組成では C18：0が青色照明区で低い值を示し, 無灯火区と青色照明区間に有意 な差が見られた（P<0.05）。また, C18:2では無灯火区が低い值を示し, 無灯火区と赤色 照明区間に有意な差が見られた $(\mathrm{P}<0.05)$ 。胸最長筋内脂質の脂肪酸組成では $\mathrm{C} 14: 0$ が無 灯火区で高い值を示し，無灯火区と白熱灯照明区間に有意な差が見られた（P<0.05）。ま た C18：0 では赤色照明区が高い值を示し，無灯火区と赤色照明区間，赤色照明区と青色 照明区および白熱灯照明区間に有意な差が見られた（P<0.05）。その飽和脂肪酸は赤色照 明区が高い值を示し，赤色照明区と青色照明区および白熱灯照明区間，青色照明区と白熱 灯照明区間に有意な差が見られた（P<0.05）。また不飽和脂肪酸は赤色照明区が低い值を 示し，赤色照明区と青色照明区および白熱灯照明区間に有意な差が見られた $(\mathrm{P}<0.05)$ 。 さらに不飽和脂肪酸に対する飽和脂肪酸の比では赤色照明区が高い值を示し, 赤色照明区 と青色照明区および白熱灯照明区間に有意な差が見られた $(\mathrm{P}<0.05)$ 。血中脂質成分では, 中性脂肪, 総コレステロールおよび HDL-コレステロール量は各区間に有意な差は見られ なかった。しかし，総コレステロールに対する HDL-コレステロール比では青色照明区が 低い值を示し，青色照明区と赤色照明区間に有意な差が見られた $(\mathrm{P}<0.05)$ 。
\end{abstract}

\section{緒言}

視覚は多くの脊椎動物にとって外部環境を認識
する上で重要な感覚の一つである。家禽において は古くから照明管理により産卵率向上や悪癖防止 の工夫がなされてきたが1)，現在，豚においては

Effect of Illumination Color on Growth, Carcass Characteristics, and Fatty Acid Composition of Lipid and Muscle Tissues in Pigs

M. Yamada, N. Hirayama, K. Yamada*, S. Sugita** and Y. Yamauti

Fukushima Prefectural Agriculture College, Yabuki-mati Fukusima-ken 969-0292

* Faculty of Living Science, Koriyama Women's College, Koriyama-shi Fukushima-ken 9638851

** Faculty of Agriculture, Utsunomiya University, Utunomiya-shi, Tochigi-ken 321-8505 
照明管理は一般的に行われていない。

しかし, 泌乳豚に明 16 時間, 暗 8 時間の光周期 を与えた場合, 明 8 時間, 暗 16 時間の光周期を与 えた場合に比べて，その総乳固形分が増加すると ともに，その同居哺乳子豚の発育が高まり，次回 発情あ早まったとする報告や ${ }^{2,3)}$, 雄豚に明 15 時 間, 暗 9 時間の光周期を与えた場合, 増体量や飼 料効率等には差がなかったものの，自然光を与え られた群に比べ性成熟が早まったとする報告があ り ${ }^{4)}$, 豚においてあ種々な生理活動が視覚情報に 影響を受けているところが比較的多いと考えられ る。さらに, ヒトの中枢神経反応や自律神経反応 が色温度に大きく影響を受け，さまざまな生理活 動を引き起こしていることあ報告されており

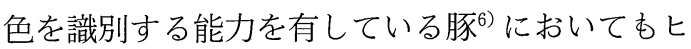
トと同様, 色の種類が様々な生理活動に影響を与 える可能性が示唆される。

そこで本研究では, 照明管理による豚の発育環 境の改善の可能性を検討するため, 24 時間, 赤色 および青色照明, 白熱灯照明点灯下における肥育 豚の発育性, 産肉性および脂肪組織と筋肉の脂肪 酸組成への影響について検討した。

\section{材料および方法}

本研究には母豚 5 腹から生産された三元交雑豚 雌 24 頭を用いた。使用豚舎はカーテン開閉式豚 舎であり, 試験期間は, 昼間はカーテンを開け, 夜間は閉めた。各豚房には豚房床から高さ 200 $\mathrm{cm}$ に家畜用電球ホルダーに赤色あるいは青色の カラービーム電球または白熱灯電球であるハイ ビーム電球（ナショナル製：110 V, $80 \mathrm{~W}$ ）を付け た照明を 24 時間点灯した。飼養形態は各群 2 頭 群飼であり, 供試豚 24 頭は, 赤色照明を設置した 豚房で飼養した赤色照明区に 3 群で 6 頭，青色照 明を設置した豚房で飼養した青色照明区に 3 群で 6 頭，白熱灯照明を設置した豚房で飼養した白熱 灯照明区に 3 群で 6 頭, 照明を設置しない豚房で 飼養した無灯火区に 3 群で 6 頭で, 各腹から各区 になるべく均等になるように分けた。なお，各試 験期間肥育後期における任意 5 日間の午前 10 時 （晴天時）および午後 10 時の平均照度（豚房床か ら $65 \mathrm{~cm}$ の位置にて測定) は, 赤色照明区で
749.5 lux, 74.7lux， 青色照明区で 487.6 lux, 33.5 lux, 白熱灯照明区で $1304.11 \mathrm{ux}, 665.2 \mathrm{lux}$, 無灯 火区で 396.4 lux, 0 lux であった。

各豚は 24 時間各照明下において体重約 30-65 $\mathrm{kg}$ までは市販の肥育前期飼料（粗タンパク質: $15.5 \%$ 以上, 粗脂肪: $2.5 \%$ 以上, $\mathrm{TDN}: 78.0 \%$ 以 上), 体重約 65 以降試験終了の $105 \mathrm{~kg}$ 以上まで は市販の肥育後期飼料（粗タンパク質 : $13.5 \%$ 以 上, 粗脂肪: $2.5 \%$ 以上, TDN : $77.0 \%$ 以上）を給 与し, 飼料と水は自由摂取とした。各供試豚は屠 殺前に絶食させ, 絶食 10 時間後に前大静脈より 採血し, 約 24 時間後に屠殺, 枝肉とした。枝肉は $4^{\circ} \mathrm{C}$ 冷蔵庫で 24 時間放冷した後, 枝肉重量々背脂 肪の厚さを測定し, 右半丸より第 $4 \cdot 5$ 胸椎間背 脂肪と胸最長筋をサンプリングした。なお, 各区 における試験開始体重, 肥育前期飼料から後期飼 料への切り替え時体重, 試験終了体重は表 1 に示 した。

採取した血液は, 遠心分離 $(3,000 \mathrm{rpm} \cdot 10$ 分) を行い, その上清を分注し, 分析まで $-30^{\circ} \mathrm{C}$ で保 存し, 血清脂質の分析に供した。なお, 本研究で 供した血清は，押田らが報告している溶血血清見 本7)の（一）および (土) と肉眼的に判断したもの である。血清中の中性脂肪はグリセロキナーゼ, L- $\alpha$-グリセロリン酸オキシターゼを用いたワン ステップ酵素法による市販のキット（株式会社ヤ トロン製クリンテック TG-S), 総コレステロール の分析はコレステロールエステラーゼ，コレステ ロールオキシターゼを用いたワンステップ酵素法 による市販のキット（株式会社ヤトロン製イアト ロンリポTG), HDL (高比重リポタンパク質) コ レステロールはデキストラン硫酸, $\mathrm{Mg}$, リンタ ングステン酸法とコレステロールエステラーゼ, コレステロールペルオキシターゼを用いたワンス テップ酵素法による市販のキット（株式会社ヤト ロン製イアトロンリポハイコレスト）を用いてそ れぞれ測定した。

採取した背脂肪および胸最長筋の脂質は，クロ ロホルムとメタノール $(2: 1)$ 混合液を加え, ヒ スコトロン（株式会社日音医理科機械製作所製） でホモジナイズし，FoLCH 法8) に準じて抽出精製 した。胸最長筋の脂質含量は重量法, 背脂肪およ 
び胸最長筋内脂質の脂肪酸組成は抽出した脂質を $5 \%$ 塩酸メ夕ノールでメチル化した後, 日立 G3500 型ガスクロマトグラフィーで分析した。な お, 脂肪酸の分析は, チャピラリーカラム (CP-sil 88 , for FAME $50 \mathrm{~m} \times 0.25 \mathrm{~mm}$ ) を用い, 注入温度 $270^{\circ} \mathrm{C}$, カラム温度 $190^{\circ} \mathrm{C}$, ディテクター温度 $300^{\circ} \mathrm{C}$ の条件で行った。

実験結果の有意差検定はSTUDENT および WELCH の $\mathrm{t}$ 検定で行った。

\section{結果}

本研究では, 赤色照明, 青色照明, 白熱灯照明 を設置した各区，および照明を設置しない無灯火 区における, 肥育豚の発育性, 産肉性および脂肪
組織と筋肉の脂肪酸組成について比較検討した。

\section{1. 発育調查および枝肉調査}

各区における肥育前期, 肥育後期および試験期 間全体の一日平均増体量と飼料要求率, 出荷前体 重, 枝肉重量, 枝肉歩留, 背脂肪の厚さを表 1 に 示した。肥育前期, 後期および試験期間全体の一 日平均増体量および飼料要求率は, 各区間に有意 な差は見られなかった。

また, 出荷前体重, 枝肉重量, 枝肉歩留, 背脂 肪の厚さについても各区間に有意な差は見られな かった。

\section{2. 背脂肪の脂肪酸組成亡胸最長筋内脂質含量 およびその脂肪酸組成}

背脂肪の脂肪酸組成を表 2 に, 胸最長筋内脂質

表 1. 各区に打ける試験開始体重, 飼料切り替え体重, 終了時体重, 一日平均増体量, 飼料要求 率, 出荷前体重, 枝肉重量, 枝肉歩留, 背脂肪の厚さ

Table 1. Starting Weight, Changing Food Weight, Finishing Weight, Daily Weight Gain and Food Convertion Rate Final Weight, Carcass Weight, Dressed Carcass Percentage and Backfat Thickness in each group of Pigs.

\begin{tabular}{|c|c|c|c|c|}
\hline & $\begin{array}{l}\text { Non-Lamp } \\
\quad(\mathrm{n}=6)\end{array}$ & $\begin{array}{l}\text { Red Lamp } \\
\quad(\mathrm{n}=6)\end{array}$ & $\begin{array}{l}\text { Blue Lamp } \\
\quad(\mathrm{n}=6)\end{array}$ & $\begin{array}{l}\text { Incandescent Lamp } \\
\qquad(\mathrm{n}=6)\end{array}$ \\
\hline Starting Weight (kg) & $31.5 \pm 3.3$ & $30.8 \pm$ & $29.9 \pm 3.8$ & $31.8 \pm 3.8$ \\
\hline Changing Food Weight (kg) & $67.4 \pm$ & $63.7 \pm$ & $66.8 \pm 7.0$ & $67.0 \pm 4.0$ \\
\hline Finishing Weight (kg) & $107.0 \pm 2.1$ & $108.2 \pm 1.6$ & $106.4 \pm 1.3$ & $106.5 \pm 1.1$ \\
\hline \multicolumn{5}{|l|}{ Daily Weight Gain (g) } \\
\hline Growing Stage $\mathrm{e}^{1)}$ & $832.3 \pm 109.7$ & $764.5 \pm 75.8$ & $854.2 \pm 104.0$ & $811.7 \pm 72.1$ \\
\hline Finishing Stage ${ }^{2)}$ & $814.6 \pm 89.7$ & $797.6 \pm 140.9$ & $875.1 \pm 127.0$ & $860.3 \pm 130.1$ \\
\hline Total Stage ${ }^{3)}$ & $825.0 \pm 96.4$ & $781.2 \pm 111.3$ & $865.9 \pm 106.3$ & $836.6 \pm 95.5$ \\
\hline \multicolumn{5}{|l|}{ Food Convertion Rate } \\
\hline Growing Stage ${ }^{1)}$ & $2.25 \pm$ & $2.26 \pm$ & $2.11 \pm$ & $2.27 \pm$ \\
\hline Finishing Stage ${ }^{2)}$ & $3.29 \pm$ & $3.31 \pm$ & $3.18 \pm$ & $3.34 \pm$ \\
\hline Total Stage ${ }^{3)}$ & $2.80 \pm 0.26$ & $2.86 \pm 0.31$ & $2.66 \pm$ & $2.83 \pm$ \\
\hline \multicolumn{5}{|l|}{ Carcass Characteristics } \\
\hline $\mathrm{F} . \mathrm{W} \cdot{ }^{\mathrm{a})}(\mathrm{kg})$ & $103.2 \pm$ & $103.8 \pm$ & $104.8 \pm$ & $104.5 \pm$ \\
\hline C.W. ${ }^{\text {b) }}(\mathrm{kg})$ & $71.4 \pm$ & $71.8 \pm$ & $71.1 \pm$ & $72.3 \pm 2.1$ \\
\hline$(\mathrm{b}) /(\mathrm{a})(\%)$ & $69.1 \pm$ & $69.2 \pm$ & $67.9 \pm 1.3$ & $69.2 \pm 1.5$ \\
\hline Backfat Thickness (cm) & $1.7 \pm$ & $1.6 \pm$ & $1.7 \pm$ & $1.7 \pm 0.3$ \\
\hline
\end{tabular}

Note : (1) Growing stage of fattening pig, (2) Finishing stage of fattening pig, (3) Total stage of fattening pig, (a) Final Weight (the Weight before Slaughter), (b) Carcass Weight, Values show means \pm standard deviation. 
表 2. 照明の色による背脂肪の脂肪酸組成への影響

Table 2. Effect of Illumination Color on Fatty Acids Composition of Backfat.

\begin{tabular}{|c|c|c|c|c|}
\hline & $\begin{array}{l}\text { Non-Lamp } \\
\quad(\mathrm{n}=6)\end{array}$ & $\begin{array}{l}\text { Red Lamp } \\
\quad(\mathrm{n}=6)\end{array}$ & $\begin{array}{l}\text { Blue Lamp } \\
\quad(\mathrm{n}=6)\end{array}$ & $\begin{array}{l}\text { Incandescent Lamp } \\
\qquad(\mathrm{n}=6)\end{array}$ \\
\hline \multicolumn{5}{|l|}{ Fatty Acids (\%) } \\
\hline $\mathrm{C} 14: 0$ & $1.2 \pm 0.2$ & $1.2 \pm 0.3$ & $1.3 \pm 0.4$ & $1.2 \pm 0.3$ \\
\hline $\mathrm{C} 16: 0$ & $24.7 \pm 1.2$ & $24.2 \pm 2.0$ & $25.2 \pm 3.1$ & $24.2 \pm 1.4$ \\
\hline $\mathrm{C} 16: 1$ & $1.6 \pm 0.2$ & $1.4 \pm 0.4$ & $1.7 \pm 0.2$ & $1.5 \pm 0.6$ \\
\hline $\mathrm{C} 18: 0$ & $15.3 \pm 1.5^{\mathrm{a})}$ & $14.4 \pm 0.7^{\mathrm{ab})}$ & $13.8 \pm 0.5^{\mathrm{b})}$ & $14.2 \pm 1.2^{\mathrm{ab})}$ \\
\hline $\mathrm{C} 18: 1$ & $45.8 \pm 3.0$ & $45.6 \pm 1.5$ & $46.0 \pm 3.8$ & $46.9 \pm 4.1$ \\
\hline $\mathrm{C} 18: 2$ & $10.8 \pm 0.8^{\mathrm{a})}$ & $12.3 \pm 1.6^{\mathrm{b})}$ & $11.1 \pm 1.6^{\mathrm{ab})}$ & $11.1 \pm 1.5^{\mathrm{ab})}$ \\
\hline $\mathrm{C} 18: 3$ & $0.8 \pm 0.4$ & $0.8 \pm 0.3$ & $0.9 \pm 0.3$ & $0.9 \pm 0.3$ \\
\hline S. F. A. (1) & $41.1 \pm 2.6$ & $39.7 \pm 1.9$ & $40.3 \pm 4.0$ & $39.6 \pm 2.16$ \\
\hline U. S. F. A. (2) & $58.9 \pm 2.6$ & $60.2 \pm 1.9$ & $59.7 \pm 4.0$ & $0.4 \pm 2.16$ \\
\hline$(1) /(2)$ & $70.1 \pm 7.2$ & $66.1 \pm 5.2$ & $68.2 \pm 11.2$ & $5.8 \pm 5.8$ \\
\hline
\end{tabular}

Note: (1) Saturated Fatty Acid, (2) Unsaturated Fatty Acid; Values (means \pm standard deviation) with different alphabetical superscripts within a line are significantly different $(\mathrm{P}<0.05)$.

表 3. 照明の色による胸最長筋内脂質含量とその脂肪酸組成への影響

Table 3. Effect of Illumination Color on Lipid Content in Loin (M. Logissium thoracis) and its Fatty Acids Composition.

\begin{tabular}{|c|c|c|c|c|}
\hline & $\begin{array}{l}\text { Non-Lamp } \\
\quad(\mathrm{n}=6)\end{array}$ & $\begin{array}{l}\text { Red Lamp } \\
\quad(\mathrm{n}=6)\end{array}$ & $\begin{array}{l}\text { Blue Lamp } \\
\quad(\mathrm{n}=6)\end{array}$ & $\begin{array}{l}\text { Incandescent Lamp } \\
\qquad(\mathrm{n}=6)\end{array}$ \\
\hline Lipid Content (\%) & $2.95 \pm 0.7$ & $3.00 \pm 0.8$ & $2.86 \pm 0.4$ & $3.28 \pm 0.4$ \\
\hline \multicolumn{5}{|l|}{ Fatty Acids (\%) } \\
\hline $\mathrm{C} 14: 0$ & $1.6 \pm 0.2^{\mathrm{a})}$ & $1.4 \pm 0.4^{\mathrm{ab})}$ & $1.4 \pm 0.4^{\mathrm{ab})}$ & $1.4 \pm 0.2^{\mathrm{b})}$ \\
\hline $\mathrm{C} 16: 0$ & $25.2 \pm 1.7$ & $25.9 \pm 2.6$ & $25.2 \pm 2.2$ & $23.5 \pm 2.6$ \\
\hline $\mathrm{C} 16: 1$ & $2.9 \pm 0.5$ & $2.7 \pm 0.8$ & $2.9 \pm 0.8$ & $2.7 \pm 0.6$ \\
\hline $\mathrm{C} 18: 0$ & $12.4 \pm 1.6^{\mathrm{b})}$ & $14.6 \pm 1.7^{\mathrm{a})}$ & $11.4 \pm 1.5^{\mathrm{b})}$ & $12.3 \pm 1.6^{\mathrm{b})}$ \\
\hline $\mathrm{C} 18: 1$ & $47.7 \pm 4.2$ & $46.0 \pm 7.2$ & $49.4 \pm 2.3$ & $50.4 \pm 3.5$ \\
\hline $\mathrm{C} 18: 2$ & $8.2 \pm 2.4$ & $7.4 \pm 2.0$ & $7.8 \pm 1.1$ & $7.9 \pm 1.4$ \\
\hline $\mathrm{C} 18: 3$ & $0.6 \pm 0.3$ & $0.5 \pm 0.2$ & $0.4 \pm 0.2$ & $0.6 \pm 0.3$ \\
\hline $\mathrm{C} 20: 4$ & $1.4 \pm 0.8$ & $1.4 \pm 1.0$ & $1.3 \pm 0.4$ & $1.3 \pm 0.6$ \\
\hline S. F. A. (1) & $39.2 \pm 2.3^{\mathrm{abc})}$ & $41.8 \pm 3.9^{\mathrm{a})}$ & $38.0 \pm 2.0^{\mathrm{b})}$ & $37.2 \pm 3.3^{\mathrm{c})}$ \\
\hline U. S. F. A. (2) & $60.8 \pm 2.3^{\mathrm{ab})}$ & $57.8 \pm 4.4^{\mathrm{a})}$ & $61.8 \pm 2.0^{\mathrm{b})}$ & $62.9 \pm 3.3^{\mathrm{b})}$ \\
\hline$(1) /(2)(\%)$ & $64.7 \pm 6.4^{\mathrm{ab})}$ & $73.0 \pm 12.2^{\mathrm{a})}$ & $61.6 \pm 5.3^{\mathrm{b})}$ & $59.5 \pm 8.3^{\mathrm{b})}$ \\
\hline
\end{tabular}

Note: (1) Saturated Fatty Acid, (2) Unsaturated Fatty Acid; Values (means \pm standard deviation) with different alphabetical superscripts within a line are significantly different $(\mathrm{P}<0.05)$. 
含量およびその脂肪酸組成を表 3 に示した。

背脂肪の脂肪酸組成では $\mathrm{C} 18: 0$ が無灯火区で $15.3 \%$, 赤色照明区で $14.4 \%$, 青色照明区で $13.8 \%$ ，白熱灯照明区で $14.2 \%$ 之，青色照明区で 低い值を示し，無灯火区と青色照明区間に有意な 差が見られた（P<0.05）。C18: 2 では無灯火区が $10.8 \%$ ，赤色照明区が $12.3 \%$ ，青色照明区が 11.1\%，白熱灯照明区が $11.1 \%$ 之，無灯火区が低 い值を示し, 無灯火区と赤色照明区間に有意な差 が見られた $(\mathrm{P}<0.05)$ 。しかし，その他の脂肪酸 および飽和脂肪酸, 不飽和脂肪酸, 不飽和脂肪酸 に対する飽和脂肪酸の比には各区間に有意な差は 見られなかった。

胸最長筋内脂質含量では各区間に有意な差は見 られなかった。その脂肪酸組成では，C14：0が無 灯火区で $1.6 \%$ ，赤色照明区で 1.4\%，青色照明区 で $1.4 \%$ ，白熱灯照明区で $1.4 \%$ と，無灯火区が高 い值を示し，無灯火区と白熱灯照明区間に有意な 差が見られた $(\mathrm{P}<0.05) 。 \mathrm{C} 18: 0$ においては無灯 火区が $12.4 \%$ ，赤色照明区が $14.6 \%$ ，青色照明区 が $11.4 \%$ ，白熱灯照明区が $12.3 \%$ と，赤色照明区 が高い值を示し, 赤色照明区と無灯火区, 青色照 明区および白熱灯照明区間に有意な差が見られた $(\mathrm{P}<0.05)$ 。飽和脂肪酸は無灯火区が $39.2 \%$, 赤色 照明区が $41.8 \%$ ，青色照明区が $38.0 \%$ ，白熱灯照 明区が $37.2 \%$ と, 赤色照明区が高い值を示し, 赤 色照明区と青色照明区および白熱灯照明区, 青色
照明区と白熱灯照明区間に有意な差が見られた $(\mathrm{P}<0.05)$ 。不飽和脂肪酸は無灯火区が $60.8 \%$ ，赤 色照明区が $57.8 \%$ ，青色照明区が $61.8 \%$ ，白熱灯 照明区が $62.9 \%$ と赤色照明区が低い值を示し，赤 色照明区と青色照明区および白熱灯照明区間に有 意な差が見られた $(\mathrm{P}<0.05)$ 。不飽和脂肪酸に対 する飽和脂肪酸比は無灯火区が $64.7 \%$ ，赤色照明 区が $73.0 \%$ ，青色照明区が $61.6 \% ，$ 白熱灯照明区 が 59.5\%で，赤色照明区が高い值を示し，赤色照 明区と青色照明区および白熱灯照明区間に有意な 差が見られた $(\mathrm{P}<0.05)$ 。

\section{3. 血清脂質成分}

各区における血清脂質成分を表 4 に示した。血 清中性脂肪濃度, 総コレステロール濃度, HDLコレステロール濃度は各区間に有意な差は見られ なかった。しかし，総コレステロール濃度に対す る HDL コレステロール濃度比は無灯火区が $47.8 \%$, 赤色照明区が $47.8 \%$ ，青色照明区が $41.0 \%$ ，白熱灯照明区が $46.3 \%$ 之，青色照明区が 低い值を示し，赤色照明区と青色照明区間に有意 な差が見られた（P<0.05）

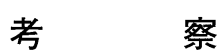

\section{1. 発育調查および枝肉調查}

WheELHOUSE and HACKER ${ }^{9)}$ は，一日 16 時間の み赤色光, クールホワイト光, 太陽光, 紫外線光 を照射した光線管理豚房で，平均体重 $46 \mathrm{~kg}$ の雄

表 4 照明の色による血清中中性脂肪濃度, 総コレステロール濃度, HDL（高比重リポタンパク 質)，総コレステロール濃度に対する HDL-コレステロール濃度の割合への影響

Table 4. Effect of Illumination Color on Concentrations of Serum Triglycerid, Total Cholesterol, HDL (High Density Lypoprotein)-Cholesterol and the Concentration Ratio of HDL-Cholesterol to Total Cholesterol.

\begin{tabular}{lcccc}
\hline \hline & $\begin{array}{c}\text { Non-Lamp } \\
(\mathrm{n}=6)\end{array}$ & $\begin{array}{c}\text { Red Lamp } \\
(\mathrm{n}=6)\end{array}$ & $\begin{array}{c}\text { Blue Lamp } \\
(\mathrm{n}=6)\end{array}$ & $\begin{array}{c}\text { Incandescent Lamp } \\
(\mathrm{n}=6)\end{array}$ \\
\hline Triglycerid $(\mathrm{mg} / \mathrm{dl})$ & $29.8 \pm 13.0$ & $37.2 \pm 35.1$ & $30.7 \pm 12.6$ & $23.2 \pm 7.6$ \\
Total Cholesterol $(\mathrm{mg} / \mathrm{dl})^{(1)}$ & $69.5 \pm 8.9$ & $69.9 \pm 7.4$ & $70.7 \pm 11.5$ & $78.0 \pm 20.6$ \\
HDL-Cholesterol $(\mathrm{mg} / \mathrm{dl})^{(2)}$ & $33.2 \pm 6.4$ & $33.3 \pm 2.5$ & $29.3 \pm 8.6$ & $35.1 \pm 6.8$ \\
$(2) /(1)(\%)$ & $47.8 \pm 7.5^{\mathrm{ab})}$ & $47.8 \pm 3.2^{\mathrm{a})}$ & $41.0 \pm 7.6^{\mathrm{b})}$ & $46.3 \pm 8.0^{\mathrm{ab})}$ \\
\hline
\end{tabular}

Note: Value (means \pm standard deviation) with different alphabetical superscripts within a line are significantly different $(\mathrm{P}<0.05)$. 
豚を 10 週間飼養した結果，一日平均増体量およ び飼料効率には差はなかったと報告している。 カーテン開閉式豚舎で 24 時間各照明を点灯した 本研究の結果では, 肥育前期, 肥育後期および試 験期間全体の一日平均増体量および飼料要求率に おいて，各区の豚の值にばらつきが見られたた め，各区間に有意な差は見られなかった。これら の結果, 照明の種類は一日平均増体量及び飼料の 利用性に及ぼす影響は少ないことが示唆された。

また, 各区における出荷前体重, 枝肉重量, 枝 肉歩留, 背脂肪の厚さには差は見られなかった。 したがって，照明の色は枝肉形質に影響を及ぼさ ないことが考えられた。

\section{2. 背脂肪の脂肪酸組成亡胸最長筋内脂質含量 およびその脂肪酸組成}

一般に, 豚脂肪組織の脂肪酸組成は, 品種 ${ }^{11,12)}$, 給与飼料の脂肪酸組成 ${ }^{13,14)}$ に影響を受ける他, 環 境温度にも影響を受けることが知られている ${ }^{15)} 。$ 一方, 光刺激之自律神経系, ひいては栄養代謝之 の間には関連が見られることが報告されてい $3^{16)}$ 。照明環境による脂肪組織と筋肉の脂肪酸組 成への影響を検討した本研究の結果, 背脂肪の脂 肪酸組成においては，C18：0 は無灯火区と青色 照明区間に，また $\mathrm{C} 18 ： 2$ では赤色照明区と無灯 火区間に有意な差が見られた。また，筋肉内脂質 においてもその脂質含量には各区間に有意な差は 見られなかったものの, その脂肪酸組成では C14：0で白熱灯照明区と無灯火区間に, C18：0 では赤色照明区と無灯火区，青色照明区および白 熱灯照明区間にそれぞれ有意な差が見られた。本 研究では, 供試品種および給与飼料, 環境温度は ほぼ統一しており, 供試豚の各区への腹ごとの配 分あほぼ平均的に行ったため, これらの脂肪酸組 成の違いは, 照明環境が豚の自律神経系, ひいて は栄養代謝に作用した結果と推察される。

また，一般にヒトにおいて飽和脂肪酸濃度が高 い油脂を㩒取することにより血中コレステロール 濃度が上昇し, 不飽和脂肪酸では逆に低くなるこ とが知られている ${ }^{17)}$ 。本研究で背脂肪の脂肪酸組 成における飽和脂肪酸, 不飽和脂肪酸, 不飽和脂 肪酸に対する飽和脂肪酸比においては各区間に有 意な差は見られなかったが，筋肉内脂質における
飽和脂肪酸は赤色照明区が高い值を示し, 赤色照 明区と青色照明区および白熱灯照明区，青色照明 区と白熱灯照明区間に有意な差が見られ，逆に不 飽和脂肪酸は赤色照明区が低い值を示し, 赤色照 明区と青色照明区および白熱灯照明区間に有意な 差が見られた。その結果, 不飽和脂肪酸に対する 飽和脂肪酸比は赤色照明区が高い值を示し, 赤色 照明区と青色照明区および白熱灯照明区間に有意 な差が見られた。よって, 赤色照明下で飼養した 豚に比べ青色または白熱灯照明下で飼養した豚の 肉の方がその脂質の脂肪酸組成から見て, ヒトの 健康によいことが考えられる。

\section{3. 血清脂質成分}

各区における中性脂肪濃度, 総コレステロール 濃度, HDL-コレステロール濃度には有意な差は 見られたかった。しかし, 総コレステロール濃度 に対する HDL-コレステロール濃度比は青色照明 区が最む低い值を示し，赤色照明 区と青色照明 区間に有意な差が見られた。これらの結果から， 照明の色によって中性脂肪濃度, 総コレステロー ル濃度, HDL-コレステロール濃度には影響を与 えないものの, 総コレステロール濃度に対する HDL-コレステロール濃度比は影響を受けている ことが考えられた。

以上の発育成績, 枝肉成績, 脂肪組織と筋肉の 脂肪酸組成等の結果から，照明の色は豚の発育性 や飼料の利用性には大きな影響を与えなかった が, 脂肪組織と筋肉の脂肪酸組成に影響を与え た。しかし，本研究では色のみに注目し，今回は 各区の照明の照度の統一は行えなかった。今後は 色と照度を含めた更なる研究が必要であると考え る。

一方，ヒトにおいて色温度が高い光は, 血圧の 上昇等の自律神経の興奮作用六進 ${ }^{5)}$, 中枢神経の 興奮作用による高い覚醒水準の誘発作用があ $り^{5,10)}$ ，快適な環境とはいえないことが知られて いる。豚は青だけを明度の差でなく色として識別 することが報告されているが ${ }^{6)}$ ，今後は照明の色 温度に対する豚の快適環境の検討法として，心電 図や脳波等の電気生理学的手法を取り入れた検討 屯必要之考える。 


\section{謝}

辞

本研究において枝肉調査および脂肪組織のサン プリングにご協力いただきました JA 福島経済連 畜産生産一課 小松良雄氏，高久英寿氏，JA 東 西しらかわ中畑支店下重勝則氏に感謝します。

\section{文献}

1）野附 巌・山本偵紀 : 家畜の管理，IV. 家 畜の管理作業と管理方式, 4. 採卵鶏, ブロ イラーの管理 (2) 養䳕経営の生産性を高め るための要件, P169-178, 文永堂出版株式 会社，東京，1998.

2) Stevenson, J.S., Pollmann, D.S., Davis, D. L. and Murphy, J.P. : Influence of supplemental light on sow performance during and after lactation, J. Anim. Sci., 56, 1282-1286. 1983

3) Mabry, J.W., Coffey, M.T. and Seerlety, R.W. : A comparison of an 8-versusu 16hour photoperiod during lactation on suckling frequency of the baby pig and maturnal performance of the sow, J. Anim. Sci., 57, 292-295, 1983.

4) Berger, T., Mahone, P., Svoboda, K.W. Metz, W. and ClegG., E.D. : Sexual maturation of boars and growth of swine exposed to extended photoperiod during decreasing natural photoperiod, J. Anim. Sci., 51, 672-678, 1980.

5）勝浦哲夫, 光の質で人間の生理反応は影響 されるのか, 照明学会誌, 84 (6), 350-353, 2000.

6) Tanida, H., Senda, K., Suzuki, S., Tanaka, T. and Yoshimoto, T. : Color discrimination in pigs, Anim. Sci. Technol (Jpn), 62 (11), 1029-1034, 1991.

7）押田敏雄 - 吉川康宏 - 小林義浩・坂田亮 一・田中享一, 食用色素による豚溶血血清 色見本の試作について, 日豚会誌, 25 (3), 119-123, 1988.

8) Folch, J., Lees, M., and Sloane Stanley, G.H. : A simple method for the isolation and purification of total lipides from animal tissues, J. Biol. Chem., 226, 497509, 1957.

9) Wheelhouse, R.K. and Hacker, R.R. : The effect of four different types of fluorescent light on growth, reproductive performance, pineal weight and retinal morphology of Yorkshire gilts, Can. J. Animal Sci., 62, 417-424, 1982.

10）勝浦哲夫：人間工学/生理人類学における 信号処理, J.Signal Processing, 2-1，1318, 1998.

11）山野 裕・松岡昭善 - 古川 徳 - 高橋 強・山中良忠: 大ヨークシャー種, バーク シャー種およびデュロック種筋肉脂質の脂 肪酸組成，日豚会誌，33（2)，30-40，1996.

12）鈴木啓一・阿部博行・小川ゆう子・石田光 晴・清水隆弘・鈴木惇 : 3 元交雑豚の肉質 に及ぼす止め雄品種の影響, 日畜会報, 68 (3), 310-317, 1997.

13）高田良三・設楽 修・斉藤 守・森 淳： 中鎖脂肪給与が肥育豚の発育, 消化率, 背 脂肪および脂肪酸組成に及ぼす影響，日豚 会誌, 29（1）, 32-39, 1992.

14）山田未知・網中 潤・山田幸二 : 豚の脂肪 組織と筋肉における脂肪酸組成に及ぼすエ ゴマ種実の影響, 日豚会誌, 38 (1)，25-30, 2001.

15）高橋敏能・鈴木淳一 - 池田直弥 - 萱場猛 夫 : 異なる環境温度が肉豚の肥育成績と肥 育に伴う体脂肪の性状に及ぼす影響, 日豚 会誌，28（4），261-264， 1991.

16） Carda-Reverter, J.M., Zanuy, S., CarRILLO, M. and MADRID, J.A. : Time-course studies on plasma glucose, insulin, and cortisol in sea bass (Dicentrarchus labrax) held under different photoperodic regimes, Physiol. Behav., 64 (3), 245-250, 1998.

17）萩原和夫 - 岩田章子 - 片桐充昭 - 末田香 里・杉崎清子・鈴木 正・谷 政八・田村 明・細谷徳治 : 栄養学総論, 第 6 章栄養素 の代謝と機能, 脂肪の栄養 P89-91, 中央法 規出版株式会社, 東京, 1994. 


\section{Effect of Illumination Color on Growth, Carcass Characteristics, and Fatty Acid Composition of Lipid and Muscle Tissues in Pigs.}

Michi Yamada, Noriko Hirayama, Koji Yamada*, Shoei Sugita** and Yoshihiko Yamauti

Fukushima Prefectural Agriculture College, Yabuki-mati Fukusima-ken 969-0292

* Faculty of Living Science, Koriyama Women's College, Koriyama-shi Fukushima-ken 963-8851

** Faculty of Agriculture, Utsunomiya University, Utunomiya-shi, Tochigi-ken 321-8505

We studied the effect of illumination color on the growth, meat production and fatty acid composition in lipid and muscle tissues of pigs. Twenty-four three-way crossbred pigs (Landrace $\times$ Large White $\times$ Duroc) were used. The pigs were divided into 4 groups of 6 ; red lamp, blue lamp, incandescent lamp, and no lamp (control) groups. Initially, all of them were fed the food for growing stage of fattening pig approximately 30 to $65 \mathrm{~kg}$ of body weight, and then they were fed the food for finishing stage of fattening pig until about $105 \mathrm{~kg}$ of body weight under the specified illumination which came from in two lamp heads.

There were not significant difference in daily weight gain and the amount of feed convertion ratio among the four groups. Result of dressed carcass percentage and back fat thickness showed no significant difference among the four groups.

As for the fatty acid composition of back fat, the blue lamp group showed the lowest value in $\mathrm{C} 18$ : 0 content, and a significant difference was seen between that group and the control $(\mathrm{P}<0.05)$. In $\mathrm{C} 18: 2$ concentration, the lowest value of the control group was significantly different from that of red lamp group $(\mathrm{P}<0.05)$.

There were no significant differences in loin lipid content among any group. However, when the fatty acid composition of intramuscular fat was examined, the control group showed the highest $\mathrm{C} 14: 0$ concentration value, and which was significantly different from that of the incandescent lamp group ( $\mathrm{P}<0.05)$. In the concentration of $\mathrm{C} 18: 0$, the red lamp group showed the highest value, and significant differences between the four groups were seen as follows: between red lamp group and control group $(\mathrm{P}<0.05)$, between red lamp group and blue lamp group $(\mathrm{P}<0.05)$, and between red lamp group and incandescent lamp group $(\mathrm{P}<0.05)$. In comparison of saturated fatty acid content, red lamp group showed the highest value, and significant differences between the four groups were seen as follows: between red lamp group and blue lamp group $(\mathrm{P}<0.05)$, between red lamp group and incandescent lamp group $(\mathrm{P}<0.05)$, and between blue lamp group and incandescent lamp group $(\mathrm{P}<0.05)$. Moreover the red lamp group demonstrated lower levels of unsaturated fatty acid concentration, and significant differences were seen among that group and the blue and incandescent lamp groups $(\mathrm{P}<0.05)$. The red lamp group also showed the highest proportion of saturated fatty acid to unsaturated fatty acid concentrations, indicating blue lamp group and incandescent lamp group 
different significantly from each other $(\mathrm{P}<0.05)$.

Significant differences were not seen in triglyceride, total cholesterol, and HDL-cholesterol quantity among any of the groups. However, the blue lamp group had the lowest value for the proportion of HDL-cholesterol to total cholesterol, and a significant difference was seen when compared to the red lamp group $(\mathrm{P}<0.05)$.

Jpn. J. Swine Science, 39, 3 : 166-174

Key words : Illumination color, Daily weight gain and feed convertion ratio, Carcass characteristic, Fatty acid composition and Serum lipids, Pig, 